\title{
A STUDY TO DETERMINE THE EFFECT OF RELAXATION THERAPY ON ANXIETY,DEPRESSION AND STRESS AMONG DIALYSIS PATIENTS AT A SELECTED HOSPITAL, KOLKATA
}

\author{
Ms. Bhaswati Kotal Lecturer, Maa Sarada Nursing College, Durgapur, West Bengal

Prof. Ratna Biswas * Principal, Apollo Gleneagles Nursing College, Kolkata, West Bengal
*Corresponding Author \\ Ms. Bhaswati Das \\ Associate Professor, Apollo Gleneagles Nursing College, Kolkata, West \\ Bengal
}

ABSTRACT Introduction:Haemodialysis is the most common treatment for chronic renal failure patients which act as a stressor. There are evidences that this chronic condition may lead depression, anxiety and stress among the patients and relaxation therapy can reduce the severity of these psychological problems. Methodology: A quasiexperimental non randomized control group design was adopted for the study to determine the effect of relaxation therapy on anxiety, depression and stress among dialysis patients. Study participants were selected from haemodialysis patients of Apollo Gleneagles Hospital, Kolkata. Sample size was 60 which were divided into 30 patients in experimental and 30 in control group. Data were collected by DAS scale, observational checklist on Benson's relaxation therapy and practice log book on Benson's relaxation therapy at home. Results: The findings of the study revealed that there was a significant difference between post anxiety, depression and stress scores of experimental group and same of control group among dialysis patients at 0.05 level of significance after administration of relaxation therapy. Conclusion: It can be concluded that Benson's relaxation therapy is an effective measure for significant reduction of stress level among haemodialysis patients.

\section{KEYWORDS : Relaxation Therapy, Anxiety, Depression, Stress, Dialysis}

\section{INTRODUCTION}

Long term haemodialysis (HD) patients suffer from physical ,mental and as well as economical stresses and experience serious changes in lifestyle and personality. The prevalence of psychiatric hospitalization among patients who are on dialysis therapy is 1.5-3 times higher compared with other chronic diseases and adversely affects the quality of life. In several studies, the high prevalence of psychological disorders has been reported among dialysis patients. The present study was conducted to determine the effect of Benson's relaxation therapy on anxiety, depression and stress among haemodialysis patients.

\section{OBJECTIVES OF THE STUDY}

1. To assess the anxiety, depression and stress among individual dialysis patients on lst day at a selected hospital.

2. To administer relaxation therapy among experimental group of dialysis patients.

3. To determine the effect on anxiety, depression and stress among dialysis patients on respective 8 th, 15th, 30th day after administering relaxation therapy.

\section{Hypothesis}

$\mathrm{Hl}$ There will be significant differences between pre and post anxiety, depression and stress scores among dialysis patients after administering Benson's relaxation therapy.

H2 There will be significant differences between post anxiety, depression and stress scores among experimental and control group after administering Benson's relaxation therapy.

\section{MATERIALS AND METHODS}

A quasi-experimental non randomized control group in applying interrupted time series design was conducted to assess the effect of relaxation therapy on anxiety, depression and stress among dialysis patients at Dialysis unit of Apollo Gleneagles Hospitals, kolkata. Non probability sampling technique was used to select 60 haemodialysis patients from renal unit of Apollo Gleneagles Hospital,Kolkata who were divided into 30 patients in experimental and 30 patients in control group. The experimental group was trained Benson's relaxation therapy. They performed Benson's relaxation exercise twice a day for 15 minutes during the period of one month and observed the effect of it on anxiety, depression and stress by the investigators on day 8 th, 15 th, and day 30 th. Data were collected from participants by using socio-demographic proforma, DASS 21 scale to assess anxiety, depression and stress and observational checklist to assess steps of Benson's relaxation therapy.

\section{RESULTS}

Table:1 Percentage Distribution of Stress, Depression and Anxiety Scores among Experimental and Control Group on 1st $, 8^{\text {th }}, 15^{\text {th }}$, and $30^{\text {th }}$ Doy $\mathrm{N}=60,(\mathrm{nE}=30, \mathrm{nC}=30)$

\begin{tabular}{|c|c|c|c|c|c|}
\hline Observation & Mean Diff. & SD of Diff & 't' value & df & Remarks \\
\hline Day l-Day8 & 1.07 & 2.02 & $2.898^{*}$ & 29 & Significant \\
\hline Dayl-Day 15 & 2.67 & 2.25 & $6.495^{*}$ & 29 & Significant \\
\hline Day l- Day30 & 6.33 & 4.40 & $7.889^{*}$ & 29 & Significant \\
\hline
\end{tabular}

't' value with df $29=2.045, \quad \mathrm{p}<0.05 \rightarrow{ }^{*}$ significant

Data presented in table 2 showed that there were statistically significant differences in mean values of anxiety on 8th, 15th, 30 th day compared to same of list day. So, the null hypothesis is rejected and research hypothesis is accepted. Hence it can be interpreted that there was an effect of relaxation therapy for significant reduction of anxiety level among experimental group.

Table:2 Mean difference, SD Difference, $t$ value and df of Depression Scores in Experimental group before and after Administration of Benson's Relaxation Therapy on 8th, 15th, $30^{\text {th }}$ day.

\begin{tabular}{|c|c|c|c|c|c|}
\hline Observation & Mean Diff. & SD of Diff & 't' value & df & Remarks \\
\hline Day l-Day8 & 1.07 & 2.02 & $2.898^{*}$ & 29 & Significant \\
\hline Dayl-Day 15 & 2.67 & 2.25 & $6.495^{*}$ & 29 & Significant \\
\hline Day l- Day30 & 6.33 & 4.40 & $7.889^{*}$ & 29 & Significant \\
\hline
\end{tabular}

$t^{\prime}$ value with df $29=2.045, \quad \mathrm{p}<0.05 \rightarrow{ }^{*}$ significant

Data presented in table 2 showed that there were statistically significant differences in mean values of anxiety on 8th, 15th, 30 th day compared to same of list day. So, the null hypothesis is rejected and research hypothesis is accepted. Hence it can be interpreted that there was an effect of relaxation therapy for 
significant reduction of anxiety level among experimental group.

Table:3 Mean difference, SD Difference, $t$ value and $d f$ of Depression Scores in Experimental group before and after Administration of Benson's Relaxation Therapy on 8th, 15th, $30^{\text {th }}$ day $\cdot N=60,(n E=30, n C=30)$

\begin{tabular}{|c|c|c|c|c|}
\hline Observation & SD of Diff & 't' value & df & Remarks \\
\hline Day l-Day8 & 3.22 & $4.762^{*}$ & 29 & Significant \\
\hline Dayl-Day 15 & 3.41 & $6.591^{*}$ & 29 & Significant \\
\hline
\end{tabular}

Table: 3 Mean difference, SD Difference, $t$ value and df of Stress Scores in Experimental group before and after Administration of Benson's Relaxation Therapy on 8th, 15th, 30th day.

\begin{tabular}{|c|c|c|c|c|c|c|c|c|}
\hline Day of observation & lst & & 8 th & & 15 th & & 30th & \\
\hline Variables & Experimental & Control & Experimental & Control & Experimental & Control & Experimental & Control \\
\hline $\begin{array}{l}\text { 1.Stress } \\
\text { Extremely severe } \\
\text { Severe } \\
\text { Moderate } \\
\text { Mild } \\
\text { Normal }\end{array}$ & $\begin{array}{l}16.70 \\
63.30 \\
20 \\
0 \\
0\end{array}$ & $\begin{array}{l}26.70 \\
56.70 \\
13.30 \\
0 \\
3.30\end{array}$ & \begin{tabular}{|l}
3.3 \\
53.30 \\
30 \\
13.30 \\
0
\end{tabular} & $\begin{array}{l}30 \\
63.30 \\
3.30 \\
3.30 \\
0\end{array}$ & \begin{tabular}{|l}
0 \\
53.30 \\
26.70 \\
16.70 \\
3.30
\end{tabular} & $\begin{array}{l}46.70 \\
43.30 \\
6.70 \\
3.30 \\
0\end{array}$ & $\begin{array}{l}0 \\
16.70 \\
56.70 \\
16.70 \\
10\end{array}$ & $\begin{array}{l}43.30 \\
43.30 \\
10 \\
3.30 \\
0\end{array}$ \\
\hline $\begin{array}{l}\text { 2. Depression } \\
\text { Extremely severe } \\
\text { Severe } \\
\text { Moderate } \\
\text { Mild } \\
\text { Normal } \\
\end{array}$ & $\begin{array}{l}90 \\
10 \\
0 \\
0 \\
0 \\
\end{array}$ & $\begin{array}{l}70 \\
30 \\
0 \\
0 \\
0 \\
\end{array}$ & \begin{tabular}{|l}
76.70 \\
16.70 \\
6.70 \\
0 \\
0 \\
\end{tabular} & $\begin{array}{l}70 \\
30 \\
0 \\
0 \\
0 \\
\end{array}$ & \begin{tabular}{|l}
66.70 \\
26.70 \\
6.70 \\
0 \\
0 \\
\end{tabular} & $\begin{array}{l}83.30 \\
16.70 \\
0 \\
0 \\
0 \\
\end{array}$ & \begin{tabular}{|l}
60 \\
26.70 \\
13.30 \\
0 \\
0 \\
\end{tabular} & $\begin{array}{l}90 \\
10 \\
0 \\
0 \\
0 \\
\end{array}$ \\
\hline $\begin{array}{l}\text { 3. Anxiety } \\
\text { Extremely severe } \\
\text { Severe } \\
\text { Moderate } \\
\text { Mild } \\
\text { Normal } \\
\end{array}$ & \begin{tabular}{|l}
53.30 \\
16.70 \\
20 \\
6.7 \\
3.30 \\
\end{tabular} & $\begin{array}{l}60 \\
20 \\
20 \\
0 \\
0\end{array}$ & \begin{tabular}{|l}
6.70 \\
43.30 \\
26.70 \\
23.30 \\
6.70 \\
\end{tabular} & $\begin{array}{l}70 \\
20 \\
10 \\
0 \\
0\end{array}$ & \begin{tabular}{|l}
36.70 \\
26.70 \\
23.30 \\
10 \\
3.30 \\
\end{tabular} & \begin{tabular}{|l}
86.70 \\
6.70 \\
6.70 \\
0 \\
0
\end{tabular} & \begin{tabular}{|l}
16.70 \\
16.70 \\
43.30 \\
10 \\
13.30 \\
\end{tabular} & $\begin{array}{l}86.70 \\
13.30 \\
0 \\
0 \\
0\end{array}$ \\
\hline
\end{tabular}

$\mathrm{t}^{\prime}$ value with df $29=2.045, \mathrm{p}<0.05 \rightarrow{ }^{*}$ significant

Data in Table3 revealed that there was statistically significant differences in mean values of depression on 8th , 15th, 30th day compared to lst day. So, the null hypothesis is rejected and research hypothesis is accepted. Hence it can be interpreted that there was an effect of relaxation therapy for significant reduction of depression level among experimental group.

Table: 4 Mean difference, SD Difference, $t$ value and $d f$ of Stress Scores in Experimental group before and after Administration of Benson's Relaxation Therapy on 8th, 15th, $30^{\text {th }}$ day.

\begin{tabular}{|c|c|c|c|c|c|}
\hline Stress & Mean Diff. & SD of Diff 't' value & df & Significance \\
\hline Day l-Day8 & 2.83 & 3.04 & $5.103^{*}$ & 29 & Significant \\
\hline Dayl-Day 15 & 4.27 & 3.39 & $6.888^{*}$ & 29 & Significant \\
\hline Day l-Day30 & 7.33 & 3.42 & $11.754^{*}$ & 29 & Significant \\
\hline
\end{tabular}

' $t$ ' value with df $29=2.045, p<0.05 \rightarrow$ significant

Data in Table4 revealed that there was statistically significant differences in mean values of Stress Scores on 8th , 15th , 30th day compared to lst day. So, the null hypothesis is rejected and research hypothesis is accepted. Hence it can be interpreted that there was an effect of relaxation therapy for significant reduction of stress level among experimental group.

Table: 5 Mean, Mean Difference, SD and $t$ value of Anxiety Scores in Experimental group and Control group on 30th Day after Administration of Benson's Relaxation Therapy

$\mathrm{N}=60,(\mathrm{nE}=30, \mathrm{nC}=30)$

\begin{tabular}{|c|c|c|c|c|c|}
\hline Group & Mean & $\begin{array}{c}\text { Mean } \\
\text { difference }\end{array}$ & $\begin{array}{c}\text { Standard } \\
\text { deviation }\end{array}$ & $\begin{array}{c}\text { 't' } \\
\text { value }\end{array}$ & Remarks \\
\hline $\begin{array}{c}\text { Experimental } \\
\text { group } \\
\text { Control group }\end{array}$ & 13.20 & 11.67 & 5.397 & $8.453^{*}$ & Significant \\
\hline
\end{tabular}

$t^{\prime}$ value with $\operatorname{df}(58)=2.003 \mathrm{P}<0.05$ * significant

\begin{tabular}{|l|l|l|l|l|}
\hline Day l- Day30 & 3.74 & $10.247^{*}$ & 29 & Significant \\
\hline
\end{tabular}

't' value with df $29=2.045, \mathrm{p}<0.05 \rightarrow{ }^{*}$ significant

Data in Table3 revealed that there was statistically significant day compared to lst day. So, the null hypothesis is rejected and research hypothesis is accepted. Hence it can be interpreted that there was an effect of relaxation therapy for significant reduction of depression level among experimental group. differences in mean values of depression on 8th , 15th , 30th

Data presented in Table 5 showed that the mean post anxiety score of control group was greater than the mean post anxiety score of experimental group and there was statistically significant differences of mean values of anxiety scores between experimental and control group. Hence it can be interpreted that there was an effect of relaxation therapy for significant reduction of anxiety level among experimental group.

Table6:Mean, Mean Difference, SD and t value of Depression Scores in Experimental group and Control group on 30th Day after administration of Benson's relaxation therapy $N=60$, $(n E=30, n C=30)$

\begin{tabular}{|c|c|c|c|c|c|}
\hline Group & Mean & $\begin{array}{c}\text { Mean } \\
\text { difference }\end{array}$ & $\begin{array}{c}\text { Standard } \\
\text { deviation }\end{array}$ & 't' value & Remarks \\
\hline $\begin{array}{c}\text { Experimental } \\
\text { group } \\
\text { Control group }\end{array}$ & 27.20 & 7.13 & 5.372 & $5.177^{*}$ & $\begin{array}{c}\text { Significa } \\
\text { nt }\end{array}$ \\
\hline
\end{tabular}

' $t$ ' df(58) $=2.003 \quad \mathrm{P}<0.05 \quad$ *significant

Data presented in Table 6 showed that the mean post depression score of control group was greater than the mean post depression score of experimental group and there was statistically significant differences of mean values of depression scores between experimental and control group. Hence it can be interpreted that there was an effect of relaxation therapy for significant reduction of depression level among experimental group.

Table:7 Mean, Mean Difference, SD and $t$ value of Stress scores in control group and Experimental group on 30th Day after administration of Benson's relaxation therapy $=60$, $(n E=30, n C=30)$

\begin{tabular}{|c|c|c|c|c|c|}
\hline Observation & Mean & $\begin{array}{c}\text { Mean } \\
\text { difference }\end{array}$ & $\begin{array}{c}\text { Standard } \\
\text { deviation }\end{array}$ & $\begin{array}{c}\text { 't' } \\
\text { value }\end{array}$ & Remarks \\
\hline $\begin{array}{c}\text { Experimental } \\
\text { group } \\
\text { Control group }\end{array}$ & 21.20 & 10.47 & 4.859 & $8.453^{*}$ & Significa \\
nt \\
\hline
\end{tabular}

$t^{\prime} \operatorname{df}(58)=2.003 \quad P<0.05 \quad$ *significant 
Data depicted in Table 7 revealed that the mean post stress score of control group was greater than the mean post stress score of experimental group and there was statistically significant differences of mean values of stress scores between experimental and control group. Hence it can be interpreted that there was an effect of relaxation therapy for significant reduction of stress level among experimental group.

\section{DISCUSSION}

In the present study mean difference of post anxiety, depression and stress score on 30th day between experimental and control group was 2.54, 1.73 and 1.80 respectively and it was found statistically significant at 0.05 level of significance. According to findings of the study Benson's Relaxation was effective measures in decreasing the anxiety, depression and stress of dialysis patients which was congruent with the results of the studies conducted by $\mathrm{N}$ Hesmatifar , H Sadeghi, A Mahadavi et.al and F Kiani, M A H Zadeh et.l who investigated to see the effect of Benson's Relaxation on anxiety, depression and stress undergoing hemodialysis patients.Their study findings revealed that Benson's relaxation therapy reduce anxiety, depression and stress among dialysis patients.

\section{CONCLUSION}

The present study can be concluded on the basis of objectives that the Benson's relaxation therapy has an effect on reducing anxiety, depression and stress among dialysis patients.

\section{Conflict of interest: None}

\section{References:}

1. Filali A EI, Bentata Y, Ada N, Oneib Bouchra.(2017). Depression and anxiety disorders in chronic hemodialysis patients and their quality of life: A cross sectional study about 106 cases in the northeast of morocco. Saudi journal of Kidney Diseases and transplantation, 28(2): 341-348

2. Hesmatifar N, Sadeghi H, Mahadavi A. Shegarf N.M.R, Rakhashani M. H.(2015). The effect of Benson relaxation Technique on depression in patients undergoing hemodialysis. J Babol University of Medical Science, 17(8): 34-40

3. Jordanova N P, Polenkovic M.(2016). Are Depression and anxiety common in haemodialyzed patients?. Bantao Journal, 14(2):84-88

4. Kiani F, Zadeh M A H, Shahrakipour M.(2017). The effect of Benson's relaxation method on hemodialysis patient's anxiety. Biomedical Research, 28 (3): 1075-8151. www.alliedacademies.org/articles/the-effect-of-bensonsrelaxation-method-on-hemodialysis-patients-anxiety.html.

5. Kumar V, Khandelia V, Garg A.(2018). Depression and anxiety in patients with chronic kidney disease undergoing hemodialysis. Annals of Indian Psychiatry,2(2): 115

6. Mahdavi A, Gorji M A H, Gorji A M H, Yazdani J, Ardebil M D.(2013) Implementing Benson's Relaxation Training in Haemodialysis patients: Changes in Perceived stress, Anxiety and Depression. North American Journal of Medical Sciences, 5(9):537-540

7. Santhi S A, Samson R, Srikanth, Pethuru D.(2018). Effectiveness of physical activity on depression, anxiety, stress and quality of life of patients. Biomedical research, 29(9):1885-1890

8. Sorena K, Najafi A, Meybodi A M.(2016) Association between anxiety and depression with dialysis adequacy in patients on Maintenance Haemodialysis. Indian Journal of Psychiatry and Behavioural Sciences, 10(2):49-62 view at [Google Scholar] https:// www. ncbi. nlm. nih. gov/ pmcarticles/PMC5087286/

9. Yazdani J, Setareh J.(2012). Effect of Benson Relaxation response on stress among in hemodialysis patients. Journal of Mazandaran University of Medical Sciences 22(91)61-68 